\title{
Who invests in renewable electricity production? Empirical evidence and suggestions for further research
}

Anna Bergek, Ingrid Mignon and Gunnel Sundberg

\section{Linköping University Post Print}

\section{Tweet}

N.B.: When citing this work, cite the original article.

Original Publication:

Anna Bergek, Ingrid Mignon and Gunnel Sundberg, Who invests in renewable electricity production? Empirical evidence and suggestions for further research, 2013, Energy Policy, (56), 568-581.

http://dx.doi.org/10.1016/j.enpol.2013.01.038

Copyright: Elsevier

http://www.elsevier.com/

Postprint available at: Linköping University Electronic Press

http://urn.kb.se/resolve?urn=urn:nbn:se:liu:diva-89587 


\title{
Who invests in renewable electricity production? Empirical evidence and suggestions for further research
}

\author{
Anna Bergek, Ingrid Mignon* and Gunnel Sundberg \\ Department of Management and Engineering \\ Linköping University \\ SE-581 83 Linköping \\ Sweden.
}

*Corresponding author. Email: ingrid.mignon@liu.se. Tel. +4613282591

\begin{abstract}
Tranforming energy systems to fulfill the needs of a low-carbon economy requires large investments in renewable electricity production (RES-E). Recent literature underlines the need to take a closer look at the composition of the RES-E investor group in order to understand the motives and investment processes of different types of investors. However, existing energy policies generally consider RES-E investments made on a regional or national level, and target investors who evaluate their RES-E investments according to least-cost high-profit criteria. We present empirical evidence to show that RES-E investments are made by a heterogeneous group of investors, that a variety of investors exist and that their formation varies among the different types of renewable sources. This has direct implications for our understanding of the investment process in RES-E and for the study of motives and driving forces of RES-E investors. We introduce a multi-dimensional framework for analyzing differences between categories of investors, which not only considers to the standard economic dimension which is predominant in the contemporary energy literature, but also considers the entrepreneurship, innovation-adoption and institutional dimensions. The framework emphasizes the influence of four main investor-related factors on the investment process which should be studied in future research: motives, background, resources and personal characteristics.
\end{abstract}

Key words: renewable electricity production; investor types; investment

\section{Introduction}

Large investments in renewable electricity production (RES-E) are needed in order to reach the targets set in the EU renewables directive and to transform the European and global energy systems into a low-carbon economy (Jacobsson and Bergek, 2011; Masini and Menichetti, 2012). According to estimates by the IPCC (2011), global cumulative investments in RES-E will amount to 2,850-12,280 billion USD (in 2005 year prices) in 
the period of 2011-2030. ${ }^{1}$ According to estimates by Bloomberg New Energy Finance (2010), heavy global investments will be needed only to meet the pledges made in the COP15 negotiations in Copenhagen; for example, in addition to large increases in other renewable sources, over $830 \mathrm{GW}$ of wind power would have to be added by 2030 (Bird et al., 2005).

If investments of this magnitude are to be achieved, markets cannot be driven by government investments alone (Wüstenhagen and Menichetti, 2012). In order to design more effective policies to support the deployment of renewable electricity technologies, it is necessary to identify the main drivers and obstacles for self-sustaining markets to develop. For that, knowledge about the demand side of innovation, in terms of the actors who invest in RES-E and their investment decision-making processes, is needed (cf. Agterbosch et al., 2004; Enzensberger et al., 2002).

In much of the energy economics literature, investors in RES-E are described as a homogenous group of utility-type actors investing according to a profit-maximizing logic (cf. Fleten et al., 2007; Kangas et al., 2011) and who make their investment decisions based on comparisons between different electricity production plants (cf. Awerbuch, 2000; Fleten et al., 2007; Gross et al., 2010; Koo et al., 2011; Neuhoff et al., 2008; Pettersson and Söderholm, 2009; Söderholm et al., 2007). Investors are assumed to have economic motives, to be able to choose freely among different types of plants (e.g. both combined-cycle gas turbines and wind power) and different locations, and to have no alternative relevant investment options than other energy production plants.

In contrast, more qualitatively oriented studies tend to describe RES-E investors as a heterogeneous set of actors, including not only utilities but also small private investors, independent power producers and cooperatives (cf. Agterbosch et al., 2004). However, no systematic and empirically based categorization of different types of investors in all types of RES-E has been made to date. A first aim of this paper is, therefore, to empirically identify different categories of investors in RES-E. We demonstrate that the importance of utility-type actors has decreased, whereas a number of other types of actors are emerging as important investors. We also show that the relative importance of different types of investors differs from renewable to renewable.

\footnotetext{
${ }^{1}$ The lower values refer to the IEA World Energy Outlook 2009 Reference Scenario and the higher ones to
} a scenario that seeks to stabilize atmospheric $\mathrm{CO}_{2}$ concentration at $450 \mathrm{ppm}$. 
The importance of making such a categorization is that there are strong reasons to believe that different types of RES-E investors have different characteristics in terms of motives, ability to handle risk, required rates of returns, existing resources, expectations and alternative investments for example (Agterbosch et al., 2004; Dinica, 2006; Enzensberger et al., 2002; Langniss, 1996; Wüstenhagen and Menichetti, 2012). Such differences can have important consequences for the design of policies to support market development. If RES-E investors vary, different types of RES-E investors are likely to benefit from different policy designs (cf. Couture and Gagnon, 2010). Instead of implementing general market simulation policies, policy makers should take into account the types of actors whose investments they want to stimulate.

Empirical evidence of the differences between RES-E investor types is, however, rare (Wüstenhagen and Menichetti, 2012). We believe that one reason for this is the lack of a comprehensive theoretical framework for making such analyses. Previous analyses of RES-E investors (or rather RES-E investments) have to a large extent been based on a standard economic perspective. We argue that in order to get a better understanding of RES-E investors, other dimensions have also to be considered. The second aim of this paper is therefore to provide a multi-dimensional framework for understanding different categories of RES-E investors in terms of the characteristics and factors that influence their investment behavior. This framework adds three complementary dimensions of RES-E investments to the standard economic perspective: an entrepreneurship dimension, an innovation adoption dimension and an institutional dimension.

\section{Previous assumptions about RES-E investment processes and investors}

\subsection{Some assumptions about an homogeneous group of RES-E investors}

Research into RES-E from a standard economic perspective has been increasing since the 1990s. With the debate on global warming and nuclear power, it has become important to describe the incentives and hinders of investments in renewable energy and to evaluate whether - or under what circumstances - RES-E can be a good investment. 
In order to underline the advantages and disadvantages of RES-E investments, previous studies have evaluated RES-E investments in comparison with alternative investments in the energy sector (see Table 1, Column A). Some studies compare RES-E with conventional electricity production, i.e. production based on nuclear energy or fossil fuels (e.g. Awerbuch, 2003; Bode and Michaelowa, 2003; Carlson, 2002; Huang and Wu, 2008; Kahn, 1996; Söderholm et al., 2007), whereas others compare different renewable energy technologies with each other (e.g. Delmas and Montes-Sancho, 2011; Finon and Perez, 2007; Fleten et al., 2007; Muñoz et al., 2009).

Such evaluations are typically based on cost-comparisons (see Table 1, column B). An often-used approach in the energy sector is the levelized lifetime cost (LC) analysis (Awerbuch, 2003; Söderholm et al., 2007), which aims to identify the least-cost investment option (Awerbuch, 2000; Bhattacharya and Kojima, 2012). In LC analysis, the capital, operational and fuel costs associated with power generation (sometimes referred to as 'engineering costs') are discounted to give their net present value, which is then divided by the total output over the economic lifetime of the plant (Söderholm and Pettersson, 2011). ${ }^{2}$

However, a number of authors argue that the LC approach does not capture all the relevant investment costs (see Table 1, column C). Faúndez (2008) argues that cost and profit related to the project site, including productivity on site and energy transport distance, should be considered in evaluating investment benefits (cf. also Dinica, 2011; Neuhoff et al., 2008). Kahn (1996) shows how the cost for financing wind turbine projects affects the profitability of a project and argues that a lack of important equity shares increases the financial cost of renewable energy projects in comparison with the cost of conventional energy projects. The costs of uncertainty and risk should also be considered in the analysis (Donovan and Nuñez, 2012; Madlener et al., 2005). Investments in RES-E become relatively more attractive when risks related to fossil fuels, e.g. fossil price volatility and price of national economic exposure, and the modularity and reversibility of many renewable energy technologies are taken into consideration (Awerbuch, 2000, 2003; Bhattacharya and Kojima, 2012). However, uncertainties about policies, prices and regulations can also raise the risk level

\footnotetext{
2 For some examples, see Bemis and DoAngelis (1990), McVeigh et al. (2000) and Söderholm and
} Pettersson (2011). 
associated with RES-E investments, thereby making them less attractive than fossil energy sources (Finon and Perez, 2007; Söderholm et al., 2007). Several authors also stress the need to analyze energy portfolios rather than stand-alone projects (cf. Awerbuch, 2006; Bhattacharya and Kojima, 2012). Finally, Awerbuch (2000, 2003) and Carlson (2002) argue that social costs are underestimated in economic assessments which compare RES-E and conventional electricity production. When social costs are considered together with other costs and with return on investments, RES-E appears to be more cost-effective than conventional electricity production.

In addition to these points of criticism, another drawback of LC analysis is that it does not take into account the income side, but only considers costs. This is problematic for several reasons. First, the income side differs according to the alternative investment options within the energy field. In particular, it has been pointed out that RES-E investments are strongly influenced by government policy, and that this should therefore be taken into account in the analysis. A number of authors (e.g. Bode and Michaelowa, 2003; Carlson, 2002; Muñoz et al., 2009; Neuhoff et al., 2008; Pettersson and Söderholm, 2009; Söderholm et al., 2007; Söderholm and Pettersson, 2011) include policy measures such as carbon pricing, green certificates, energy taxes or bonuses for renewable energy sources. Second, investors might have other investment options than electricity production, and for these the LC approach is not relevant at all. However, we have not found any studies in the energy economic literature comparing investments in electricity production with other types of investments.

In spite of the slight disagreements among different researchers in terms of which costs to include and whether or not to include income in the analysis, all the literature cited above is very similar in that it assumes that the main goal of RES-E investments is profit maximization (or rather, cost minimization) and that RES-E investments, are therefore evaluated strictly in terms of profitability (see Table 1, columns B and C). One reason for this might be that, with few exceptions, these researchers have a common view as to who the RES-E investors are: namely large utilities and energy planners. Although this is not always explicitly mentioned in the studies, it tends to become very clear from the assumptions made in the analysis (see Table 1, column D): RES-E investors either plan portfolios including different electricity production plants within a larger energy system (cf. Awerbuch, 2006; Bhattacharya and Kojima, 2012; Carlson, 2002) or invest in very 
large plants (cf. Faúndez, 2008; Muñoz et al., 2009; Söderholm et al., 2007); they can choose the best location for their plant (apparently without having to worry about getting access to that location) (cf. Bode and Michaelowa, 2003; Dinica, 2011; Faúndez, 2008); and their investment decisions do not seem to be conditioned by consideration such as access to financial capital or other aspects of project implementation. ${ }^{3}$

To resume, energy policies are based on a number of assumptions, namely that investors aiming for profit-maximization and are a homogeneous group of large utilities or energy planners with unlimited access to relevant resources (financial as well as physical). Such assumptions may be problematic if investors are in fact a heterogeneous group with regards to motives and resources for example, since studies in related fields have shown that such differences can influence investment behaviours in various ways. This will be discussed in the following section.

\subsection{Factors that influence investment behavior: ideas from related fields}

As mentioned above, some researchers argue that the standard economic approach to RES-E investments focuses too much on the thinking of policy makers and too little on who actually invests in RES-E. In order to design useful energy policies, the key factors that influence the behaviour and actions of investors should be identified to allow a better understanding of how they make their decisions (cf., e.g., Dinica, 2006; Masini and Menichetti, 2012). However, in spite of these calls for a change in research focus, there are few empirical studies that identify factors that influence investment behavior and discuss their impact on investment behavior in the field of RES-E. In order to get some preliminary insights into factors that might influence RES-E investments, we have therefore to turn to studies of other types of investment-related decisions in the energy field:

- Studies of differences between investors and non-investors in renewable energy show that access to financial resources as well as personal characteristics, such as age, sex and risk propensity, influence people's willingness to invest (Aguilar and Cai, 2010; Bollinger and Gillingham, 2012; Drury et al., 2012). These studies also demonstrate

\footnotetext{
3 Financing of projects is dealt with in terms of (i) how to decide the balance between equity and debt (cf., e.g., Faúndez, 2008) and (ii) which interest rates to use in calculations, whereas the process and challenges of getting finance in the first place is not discussed.
} 
the importance of motives, previous experience and social networks. With regards to motives, Delmas and Montes-Sancho (2011) argue that the technological capabilities together with the extent to which utilities are motivated by profit influences their investments in renewables. With regards to previous experience and networks, studies show that access to information (Drury et al., 2012) and the earlier introduction of solar PV panels in the near neighbourhood of potential investors (Bollinger and Gillingham, 2012) have had a positive impact on the adoption of solar PV panels in California.

- Studies of providers of financial capital for investments in renewable energy plants show that their previous experience, risk propensity, motives and access to financial resources influence whether such providers decide to provide capital for RES-E investments as well as how they realize these financial decisions. For example, Wüstenhagen and Menichetti (2012) argue that previous experience of portfolio management and previous investments influence actors' proactiveness with regards to investments in renewable energy assets. Masini and Menichetti (2012) demonstrate that risk propensity and a priori beliefs about technological feasibility influence financial investors' willingness to back renewable energy projects. Risk propensity also influences investors' policy preferences (Couture and Gagnon, 2010). Barradale (2010) shows that motives and risk propensity influence investors' choices of ownership models. Actors who want to invest in RES-E for strategic reasons but who are less interested in tax credits can cooperate with "tax investors" who can use the tax credits but are not interested in renewables per se because of the risks involved (cf. also Bolinger et al., 2009; Bolinger and Wiser, 2006). She also shows that IPPs' choice between long-term contracts and spot market transactions is partly dependent on whether they need to secure finance for their project from external sources (Barradale, 2010).

- Studies of ownership models in the US renewable power sector show that access to financial capital and other assets influence the relative attractiveness of different models. For example, Wiser (1997) shows that actors who have a large asset base often rely on corporate financing and require lower returns on investments (cf. also Dinica, 2011), which makes ownership more attractive than buying renewable electricity from actors who are dependent on external project finance. Bolinger and 
Wiser (2006) and Bolinger et al. (2009) demonstrate that the business structures chosen by actors interested in developing utility-scale wind projects depend partly on their access to capital. Similarly, Drury et al. (2012) describe how available financial resources influence whether building occupants in California choose to own their own PV modules or to adopt them via third-party PV products.

To sum up, these streams of literature indicate that differences among investors in terms of investment motives (e.g. tax vs. strategic motives or degree of profit-seeking), financial and technical resources, previous experience of similar investments and various types of personal characteristics (e.g. risk propensity and access to social networks) are likely to influence both what actors decide to invest in and how they realize their investment decisions. However, although it has been suggested conceptually that RES-E investors form a heterogeneous group that varies for example in terms of financial strength and motives (Dinica, 2006; Langniss, 1996), the empirical relevance of these suggestions has not yet been demonstrated. Moreover, the abovementioned factors have been identified in a rather ad hoc way, on the basis of observations of other types of investments. This implies both that their relevance for RES-E investments remains unclear, and that other, potentially more important factors, might have been neglected. Against this background, the main research questions of this paper are the following:

(1) To what extent is the RES-E investor group indeed heterogeneous and in what way might the categories of investors differ from each other with respect to the above-mentioned factors? This question is analysed in Section 4.

(2) What are the implications of heterogeneity for further studies into investments in RES-E with regard to the influencing factors which should be included in an analysis of investor behavior and characteristics? This question is discussed in Section 5 .

\section{Methodology}

\subsection{Case selection}

In order to identify different categories of RES-E investors, we use the case of Sweden. This case was chosen for three main reasons. First, in Sweden almost all RES-E plants 
are included in the Swedish tradable green certificate system. This implies that reliable data on RES-E investors is readily available (see Section 3.2.1). Second, the Swedish electricity market is completely liberalized, which implies that, at least in theory, it is possible for actors to make independent decisions with regards to whether or not they want to invest in RES-E and, if they choose to invest, in which type. Thus, there are no strong regulatory restrictions that might prevent new types of RES-E investors from entering the market. Third, the Swedish support system for RES-E is based on a strong belief among policy makers in marked-based economic instruments, e.g. tradable green certificates and $\mathrm{CO}_{2}$ taxes. The choice of such policies tends to be based on assumptions about RES-E investors that are very close to those made in the energy economics literature described in Section 2. It is therefore interesting to see to what extent RES-E investors match these assumptions and also to what extent RES-E investor motives and investment decisions are influenced by economic factors. An analysis of the latter is beyond the scope of this paper, but is one of the themes included in the suggested analytical framework.

The choice of this specific case is expected to have some implications for the generalizability of the empirical findings:

(a) The categorization of RES-E investors might to some extent be case-dependent, i.e. had we studied another country we might have identified other RES-E investor categories. However, our categories include and go beyond all the RES-E investor types mentioned in the previous literature (see, e.g., Langniss, 1996), which indicates both that the categories are generally applicable and that our categorization has the potential to contribute to an increased understanding of RESE investors. In future research, this should however be confirmed through international comparison.

(b) The re-categorization of specific actor types to RES-E investor categories is based on an understanding of the Swedish context. This applies especially to the category of utility-type investors, in which we include not only large utilities (publicly or privately owned), but also publicly or privately owned energy companies (for further explanation, see below). For the purpose of clearly showing the growing importance of other emerging types of RES-E investors, we have chosen to merge 
these sub-categories into one. However, we are aware that in other countries some of these actors do not have a long tradition of investing in RES-E and would therefore be considered as emerging investors. Despite this, we would argue that the category 'utility types' as such is both relevant and generalizable, although its empirical application might vary from country to country.

(c) Finally, the distribution of RES-E investments among different investor categories is likely to have some case-specific features. This implies that we cannot draw the conclusion from our study that specific categories of RES-E investors are as important in other countries as they are in Sweden. However, the findings from the Swedish case at least suggest that it would be worthwhile investigating RES-E investment patterns in other countries and, provides a categorization that can be used for that purpose.

\subsection{Method for identifying and categorizing RES-E investors}

\subsubsection{Identification of RES-E investors}

In contrast to e.g. Dinica (2006) and Masini and Menichetti (2012) we define RES-E investors as actors who invest in renewable electricity production (e.g. utilities and farmers) rather than as actors who finance such investments, e.g. banks, funds, investment advisors, private equity firms or venture capitalists (Loock, 2012). The former initiate the idea for a new plant, mobilize resources to realize it and take ownership of the plant once it is in place. Electricity production then becomes part of their business. The latter provide the capital resources needed to realize the project in return for a rate of interest on loans or some similar form of payment. In reality, these two roles tend to overlap to some extent, since investor-owners most often provide some capital themselves. However, it is their role as investors in which we are primarily interested. 4

In order to identify RES-E investors, we used two main sources of data. The first is data about all the plants in the Swedish electricity certificate system, supplied by the Swedish Energy Agency from July 2012. The following types of plants are eligible for certificates:

- wind power

\footnotetext{
${ }^{4}$ It should also be noted that we are not studying investments in renewable energy technology development, but only investments in renewable electricity production plants.
} 
- solar power

- wave power

- geothermal power

- biomass-based power (with some restrictions)

- peat in combined heat and power (CHP) plants

- hydro power

- small-scale plants ( $<1.5 \mathrm{MW})$ (with some restrictions)

- new plants

- renewed operation of previously decommissioned plants

- increased capacity in existing plants

However, not all of these types are represented in the data; there are currently no wave or geothermal power plants in the system and there are only a few solar photovoltaic plants (see Section 4).

Only plants that are connected to the grid are included in the data. This implies that the share of smaller plants, and consequently also the share of emerging RES-E investors, is probably slightly underestimated. According to official wind power statistics, there were 1,492 wind turbines in operation in Sweden in July 2012, with a total installed capacity of 1,982 MW5. The TGC system data we use from the same time period includes roughly 1,550 turbines $(2,380 \mathrm{MW})$. The official system is based on voluntary reporting, which might explain the differences in numbers. This gives a clear indication that the TGC data is the most reliable data source for wind power plants in Sweden.

With regards to biomass-based power, we compared the data from the certificate system with a list of biomass power plants in Sweden supplied by the bioenergy industry association Svebio. Svebio's list of CHP and industrial back pressure plants overlaps to over 90 percent with the data in the certificate system, whereas the overlap for biogas plants is slightly less than 80 percent (Svebio's list contains 11 plants in addition to the 47 plants included in the certificate data). This implies both that the quality of the data is quite good and that the bias against small plants is limited.

\footnotetext{
${ }^{5}$ Data from www.vindstat.nu.
} 
However, with regard to solar cells, there is a clear problem with the data from the certificate system. Only 64 solar cell plants and a total of 1,352 kW are registered in the system. It is obviously difficult to reach any conclusions about the distribution of investments among different RES-E investor categories based on such limited data. We therefore complemented the certificate data with data supplied by the Swedish Energy Agency for applications granted for investment subsidies for solar cells from August 2011. Thisdata includes 480 granted applications for a total of about $6 \mathrm{MW}$ of peak capacity. All kinds of RES-E investors are eligible for support, individuals as well as both privately and publicly owned companies. It should be noted that RES-E investors apply for financial support prior to the installation of the solar cells. If the application is granted, they have to present documentation proving that the project has been completed, i.e. that the solar cells have actually been installed. Unlike the certificate system data, this data thus also includes potential RES-E investors. According to the Swedish Energy Agency, about 40 percent of the projects granted had been completed by August 2011. This implies that the number of RES-E investors is probably overestimated in this data. However, we assume that, among those who decide to discontinue their projects, no specific investor category is overrepresented and, therefore, that the share of each category of RES-E investors will be proportionally unchanged among those investors who complete their projects.

\subsubsection{Categorization of RES-E investors}

The overall aim of this research is to learn more about emerging RES-E investor types. As a first step, we therefore needed to define the concept of utility-type investors and identify these investors in the dataset. In the Swedish context, several types of companies have a long tradition of building and operating power plants: the stateowned utility Vattenfall, foreign-based utilities such as E.ON and Fortum, as well as privately owned energy companies and municipal energy companies. Before the liberalization of the electricity market in Sweden in 1996, all of these companies owned the transmission and distribution networks for electricity, the local district heating systems and the majority of the electricity production capacity. These investors all have a portfolio of heat and power plants which use different energy sources, including renewables. 
A more-detailed categorization was made of the other RES-E investors. In order to create a basis for further analysis, we divided them into a number of RES-E investor categories, using primarily two factors: type of ownership and main area of (business) activity. Information about these dimensions was retrieved from the database www.121.nu, which collects data from a number of public databases. ${ }^{6}$ Each company was identified in the database by its organization number. Subsidiaries were categorized according to their parent companies' ownership type and main area of activity.

We first distinguished between publicly and privately owned RES-E. Publicly owned RES-E investors include companies and other types of organizations owned or controlled by municipal, regional or national governments. Privately owned RES-E investors include all types of organizations owned or controlled by private actors. We further distinguished a number of different types of privately owned RES-E investors based on their form of ownership: (a) sole traders and partnerships, (b) companies (including trading partnerships, limited partnerships and limited companies) and (c) associations (including economic associations, cooperatives and community associations).

We then took into account each RES-E investor's main area of activity. For privately owned companies, this analysis was based on three types of information: description of main business activity according to the company register, the industry code according to the Swedish Standard Industrial Classification system, which is based on the NACE Rev.2 standard recommended by the EU, and information from the RES-E investors' web pages (when available). From this information, we divided companies into four categories: RES-E investors specializing in electricity production from renewable energy sources ('independent power producers', IPPs), RES-E investors diversifying into electricity production from the agriculture sector ('farmers'), RES-E investors diversifying into electricity production from another industry ('diversified companies') and RES-E investors combining electricity production with project development for other RES-E investors ('power project developers'). Information about sole traders and some types of associations is not available in this database, as they are not corporate bodies. We therefore decided not to divide these categories further.

${ }^{6}$ Ownership information are collected from Statistics Sweden and information about companies' business activities are collected from the Swedish Company Registration Office. 
The resulting categorization includes eight investor categories (see Table 3.1): utility types, publicly owned non-energy companies and organizations, IPPs, farmers, diversified companies, power project developers, sole traders and associations. It should be noted that the distinctions between some of these categories are somewhat arbitrary, since it is a matter of choice which organizational form is used for certain types of businesses. This is particularly the case for farmers, who can choose between sole tradership, partnership or various company forms both for their farms and for their RES-E plants. This implies first that the category 'sole traders' also includes some farmers. Second, some farmers choose to separate power production from farming by creating a separate RES-E company. Unless it was clear from the database that this new company was owned by a farmer, it was categorized as an IPP in our study, which implies that this category also includes some farmers. The study, therefore, underestimates the role of farmers in RES-E investments.

TABLE 3.1: CATEGORIES OF RES-E INVESTORS

\begin{tabular}{|c|c|}
\hline NAME & DESCRIPTION \\
\hline Utility types & $\begin{array}{l}\text { State- or privately owned utilities, privately owned energy companies } \\
\text { and municipal energy companies who owned the transmission and } \\
\text { distribution networks for electricity, the local district heating systems } \\
\text { and the majority of the electricity production capacity prior to the } \\
\text { liberalization of the electricity market in Sweden. Their electricity } \\
\text { production is based on both renewable and conventional energy sources. }\end{array}$ \\
\hline $\begin{array}{l}\text { Publicly owned non- } \\
\text { energy companies or } \\
\text { organizations }\end{array}$ & $\begin{array}{l}\text { Companies or organizations owned or controlled by national, regional or } \\
\text { municipal governments, whose main area of business is not energy, are } \\
\text { included. Their electricity production is based on renewable electricity } \\
\text { sources. }\end{array}$ \\
\hline $\begin{array}{l}\text { Independent Power } \\
\text { Producers (IPPs) }\end{array}$ & $\begin{array}{l}\text { Privately owned companies whose main area of business is electricity } \\
\text { production. Their electricity production is exclusively based on } \\
\text { renewable electricity sources. }\end{array}$ \\
\hline Farmers & $\begin{array}{l}\text { Privately owned companies, sole traders or partnerships whose main } \\
\text { area of business is agriculture (e.g. grains or animal keeping). Their } \\
\text { electricity production is based on renewable electricity sources. }\end{array}$ \\
\hline Diversified companies & $\begin{array}{l}\text { Privately owned companies whose business includes a main area other } \\
\text { than energy production (e.g. pulp and paper). Their electricity } \\
\text { production is based on renewable electricity sources. }\end{array}$ \\
\hline Power project developers & $\begin{array}{l}\text { Privately owned companies whose main area of business is to plan, build } \\
\text { and start operating power plants for other owners. }\end{array}$ \\
\hline Sole traders & $\begin{array}{l}\text { Individuals or partnerships who own one or several RES-E plants; } \\
\text { specialized in this or incorporate it with another main area of activity. }\end{array}$ \\
\hline Associations & $\begin{array}{l}\text { Associations, e.g. economic associations and churches that own one or } \\
\text { more RES-E plants. }\end{array}$ \\
\hline
\end{tabular}




\section{RES-E investors in renewable electricity production in Sweden}

\subsection{RES-E in Sweden}

Sweden has a long history of producing electricity from renewable sources, particularly from large-scale hydro power plants. This production was expanded in the period of 1940-70. Since the construction of a number of nuclear power reactors in the 1970s and 1980s, hydro power has contributed 40-55 percent of the annual net electricity production (on average 67 TWh during the last 25 years) (Swedish Energy Agency, 2011 b). In 2010, installed hydro power capacity in Sweden was about 16.2 GW, roughly the same as in 1996 (see Figure 4.1). ${ }^{7}$ Nuclear power capacity amounted to 9.2 GW (a 9 percent decrease from 1996). Together, large-scale hydro power and nuclear power plants supplied 84 percent of the 145 TWh of electricity that was produced in Sweden in 2010 (Swedish Energy Agency, 2011b).

Therefore, the share of other renewables in Swedish electricity production is still relatively small. Investments in wind turbines and biomass combined heat and power plants started to increase in the mid-1990s, largely as a consequence of investment subsidies and production subsidies (Johnson and Jacobsson, 2001). These policies had limited effect on RES-E deployment, however. In 2002, there was only about $270 \mathrm{MW}$ of wind power installed in Sweden, corresponding to about 0.6 TWh of the electricity generation, and only about 5.5 TWh of electricity was produced from biomass (Swedish Energy Agency, 2011b).

The same period saw the liberalization of the Swedish electricity market. This process started in 1996, and resulted in distribution and transmission being separated from trade and production and that trade and production were exposed to competition. The result was increased market concentration on the production side, with three utilities (Vattenfall, Sydkraft (later E.ON) and Fortum) producing roughly $90 \%$ of the electricity in Sweden in 2003 (Nordic Competition Authorities, 2003). ${ }^{8}$

The implementation of the tradable green certificate (TGC) system in May 2003 led to a more rapid increase in RES-E. In 2010, electricity production from renewable energy sources and peat amounted to about 18 TWh (12 percent of the total Swedish electricity

\footnotetext{
7 Electricity generation capacity data are not available before 1996.

8 Unfortunately, specific data for RES-E are not available.
} 
generation), which is an increase of 11.6 TWh from May 2003 (Swedish Energy Agency, 2011a). Almost 62 percent (11.2 TWh) of the RES-E was based on biomass and an additional 4.4 percent (0.8 TWh) came from peat. Wind power plants produced 19 percent (3.5 TWh) and small-scale hydro power plants 14 percent (2.6 TWh). In terms of installed capacity, CHP and industrial back pressure plants, which are largely based on biomass, ${ }^{9}$ increased by 48 percent from 1996 to about $4.8 \mathrm{GW}$ in 2010 (13 percent of the total), and wind power capacity increased twenty-fold to about $2.2 \mathrm{GW}$ in 2010 (6 percent of the total) (see Figure 4.1).

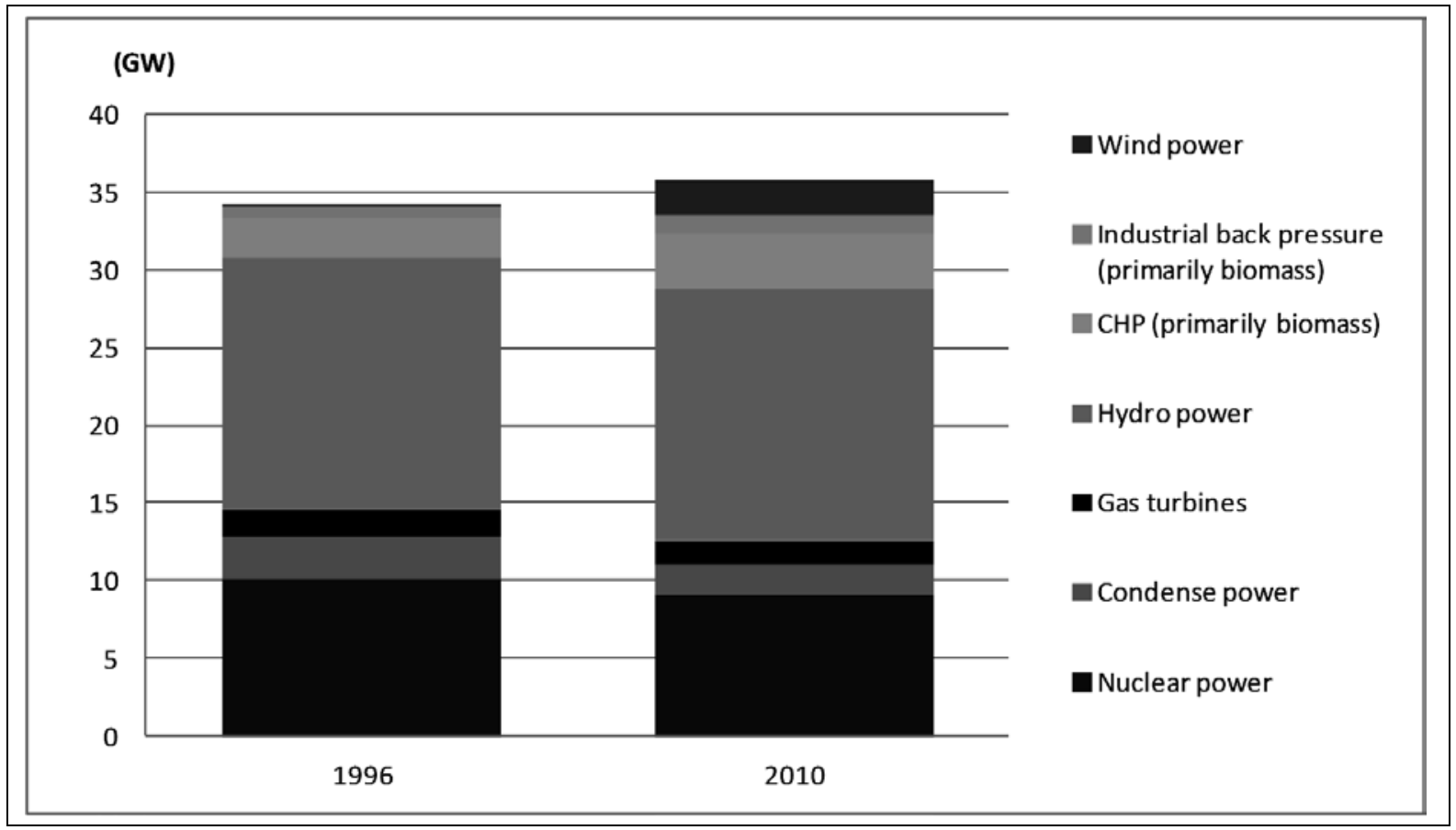

FIGURE 4.1: ELECTRICITY PRODUCTION CAPACITY IN SWEDEN 1996 VS. 2010 BY ENERGY SOURCE. SOURCE: ELABORATION ON SWEDISH ENERGY AGENCY (2011B).

\subsection{RES-E investor categories}

As shown in Figure 4.2, Swedish RES-E investments have increased rapidly in the last 20 years, both in terms of the total number of plants (approximately 2,700 new plants between 1990 and 2012) and in terms of the installed capacity (approximately 4,600 MW of new capacity). ${ }^{10}$ At the same time, the share of RES-E plants owned by utilitytype investors has decreased substantially; utility-type investors own more than 50

\footnotetext{
${ }^{9}$ On average, 67 percent of the fuels put into electricity production in these plants in the period of 2006 10 were biomass-based.

10 Years refer to the year that the plant was taken into operation.
} 
percent of the plants that were already in operation in 1990, but less than 30 percent of the plants that were in operation in July 2012.

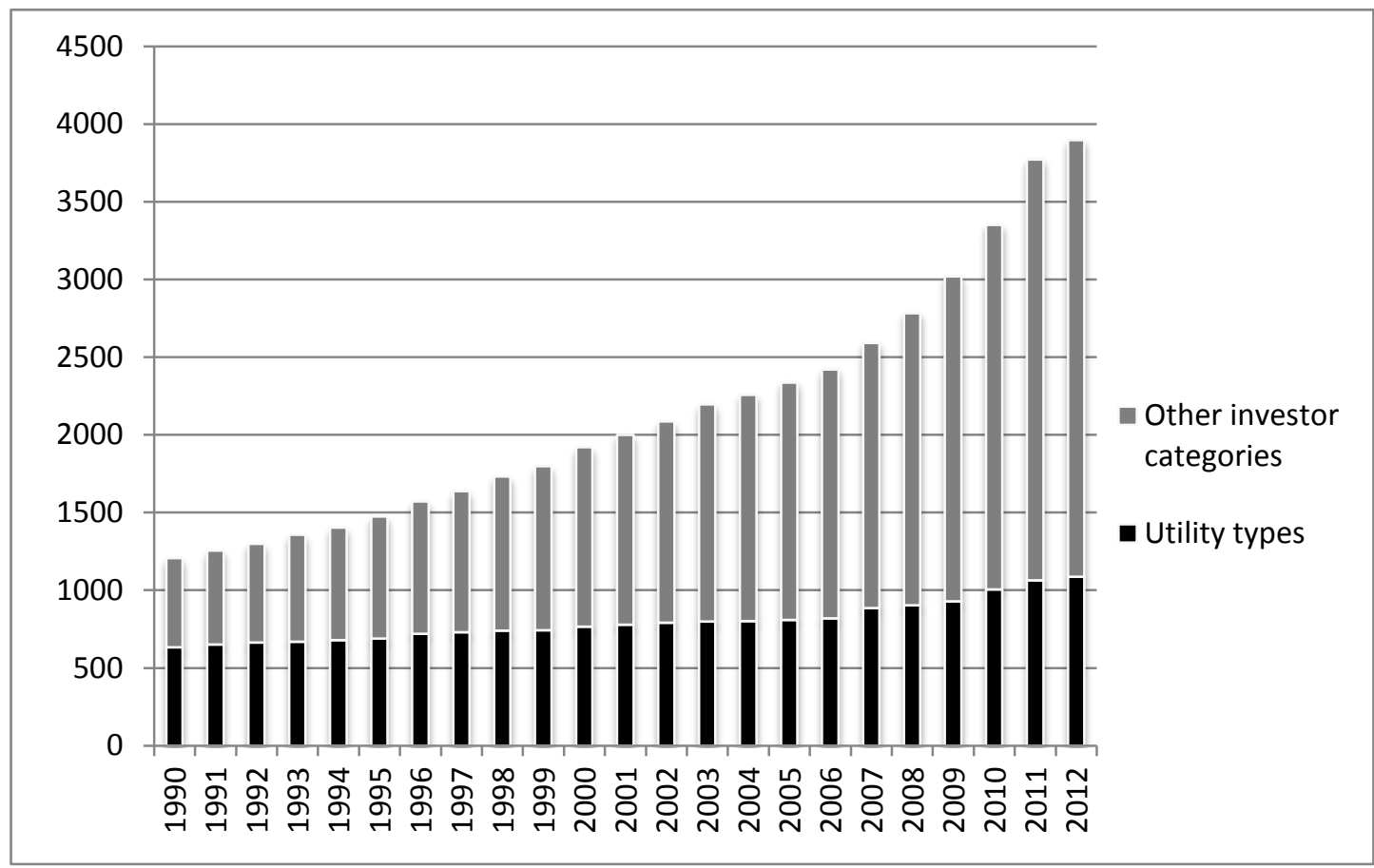

FIGURE 4.2: ACCUMULATED NUMBER OF PLANTS: UTILITY TYPES VS. EMERGING INVESTOR CATEGORIES

A more detailed overview of the shares of different investor categories in July 2012 is shown in Figure 4.3. The share of emerging RES-E investors is about 70 percent in terms of number of plants, and about 55 percent in terms of installed capacity.

When we look at the shares of RES-E investors, several outcomes are particularly interesting. First, a substantial part of the investments so far have come from emerging RES-E investor categories, i.e. sole traders, publicly-owned non-energy companies and units, associations, farmers, independent power producers (IPPs), project developers and diversified companies. Second, among the RES-E investors, a significant share of investments are made by groups that do not necessarily correspond well to the conventional image of an energy investor as described in Section 2. Finally, it is clear from this data that there is a large variety of RES-E investors, both in terms of ownership and in terms of their main area of business. Among emerging RES-E investors, the largest categories in terms of number of plants are IPPs (27 percent), sole traders (21 percent), diversified companies ( 9 percent) and project developers ( 6 percent); and in 
terms of installed capacity, diversified companies (26 percent) and IPPs (17 percent) have the largest shares.

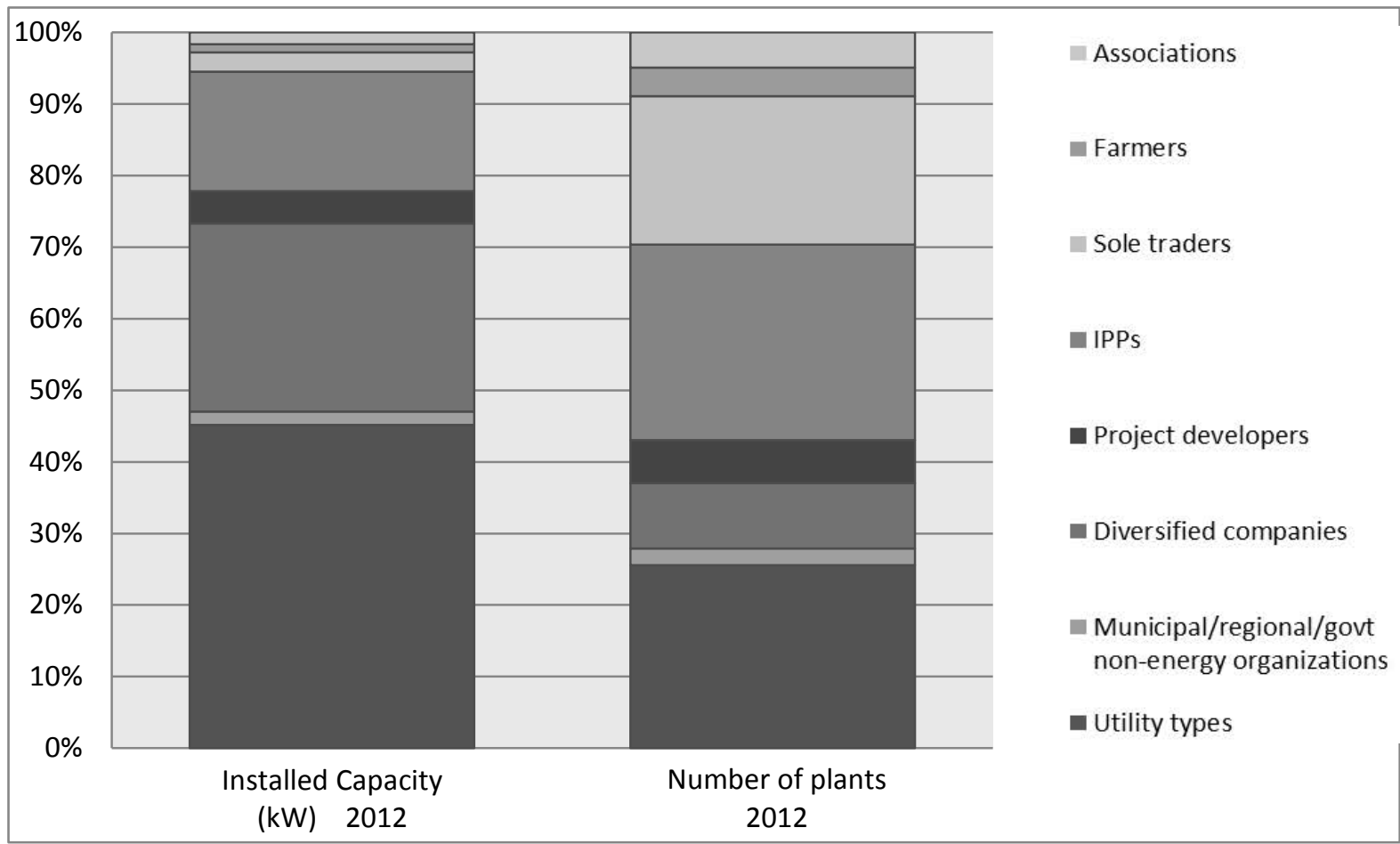

FIGURE 4.2: INVESTOR CATEGORIES, SHARES OF TOTAL NUMBER OF PLANTS AND TOTAL INSTALLED CAPACITY IN JULY 2012.

If we compare the accumulated number of plants brought into operation by 1990 and by July 2012 respectively, some RES-E investor categories seem to have invested especially heavily during this period. From 1990, IPPs have acquired almost 600 plants, representing over $870 \mathrm{MW}$ of new power capacity (from $58 \mathrm{MW}$ ). Project developers have emerged as a new category, investing in about 190 plants and over $500 \mathrm{MW}$ of new capacity. Sole traders have invested in about 430 plants and $190 \mathrm{MW}$ of new capacity (from 17 MW in 1990). ${ }^{11}$

There are, however, large differences between different renewable electricity sources in terms of who the main RES-E investors are. Figure 4.4 compares the RES-E investor patterns of biomass power, wind power and solar PV cells. The main investors in biomass-based power production plants (Figure 4.3a) are utility-type investors (49

\footnotetext{
11 It should be noted that the year when the plants were taken into operation does not correspond to the year of investment. There are problems in particular with regards to biomass plants, since the underlying district heating plants were often taken into operation long before they were converted to biomass or investments were made in electricity generators. However, the three RES-E investor categories discussed here are not so affected by these problems since they do not invest much in biomass power production (see FIGURE 4.3a).
} 
percent), diversified companies (26 percent) and publicly-owned non-energy companies (18 percent). In this case, utility-type investors comprise primarily municipal energy companies, producing biomass CHP in district heating plants. The diversified companies belong primarily to the paper and pulp industry, e.g. Södra Cell, Stora Enso, Korsnäs, SCA, Billerud and Holmen. ${ }^{12}$ The publicly-owned non-energy companies/organizations are primarily sewage and waste treatment works.

A much more diverse set of actors invests in wind power (Figure 4.3b). Here, the main RES-E investor categories are independent power producers (37 percent), sole traders (17 percent), utility types (15 percent) and wind project developers (11 percent), but associations, farmers and diversified companies also own quite a large number of wind power plants (5-7 percent each). Since company form is often a matter of choice when investing in wind power, as mentioned in Section 2, some of the sole traders and IPPs are also farmers.

With regards to hydro power (Figure 4.4c) the largest RES-E investor categories are utility types (38 percent), sole traders (27 percent) and IPPs (20 percent). For wind as well as for hydro power, utility types include both large utilities (privately or publicly owned) and municipal energy companies.

Finally, it can be seen that RES-E investors in solar PV cells (Figure 4.4c) are primarily sole traders (52 percent), publicly-owned non-energy companies/organizations (18 percent), utility types (8 percent) and diversified companies (8 percent). However, as discussed in Section 2, this data only includes 61 plants (1362 kW) in total. If instead we analyze the applications for solar PV investment subsidies made to the Swedish Energy Agency, we see that the largest category of potential RES-E investors is publicly-owned non-energy companies ( 54 percent). This is followed by sole traders ( 21 percent) and diversified companies (17 percent). In this case, publicly-owned non-energy companies are primarily municipalities and municipal landlords.

\footnotetext{
12 These six companies own over 80 percent of the diversified companies' installed capacity.
} 


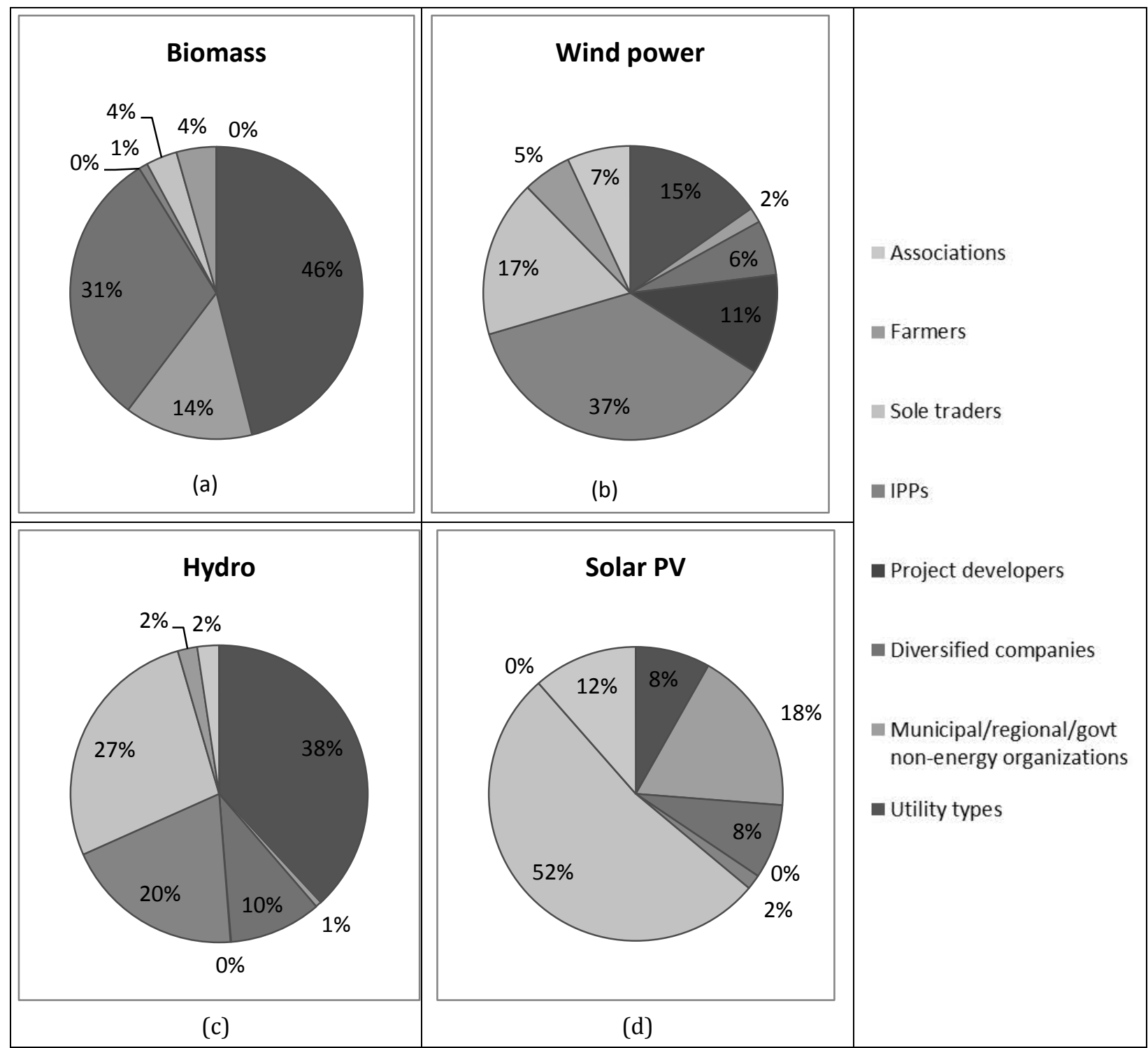

FIGURE 4.3 (A)-(D): INVESTOR CATEGORIES FOR DIFFERENT RENEWABLES, SHARES OF TOTAL NUMBER OF PLANTS IN JULY 2012

In terms of what types of companies the category diversified companies include, differences can also been seen among the four renewable. As mentioned above, companies diversifying into biomass-based power production come primarily from the paper and pulp industry, whereas companies diversifying into wind power, hydro power or solar power originate in a much more diverse set of industries, including e.g. mechanical engineering, construction consultants, paper and pulp, service management and landlords or real estate companies.

When looking at the average size of investments made in the four different renewables, it can be noted that the average investment size varies between RES-E investor categories. For instance, investments made by utility-type investors in biomass-based 
power production and in hydro power are much bigger than they are in most of the other emerging investors. For instance, the average size of investment in biomass-based power is 27.6 MW among utility-type investors, whereas it is only $65 \mathrm{~kW}$ among farmers and $95 \mathrm{~kW}$ among sole traders. In the case of hydro-power, the size of the plants that utility types generally invest in is $1 \mathrm{MW}$, whereas IPPs invest in average in $300 \mathrm{~kW}$ plants. In wind power, where the share of emerging investors is very large and most diverse, the average size of investment made by some categories of emerging investors is actually bigger than that made by utility-type investors. The average size of the investments in wind power is for instance $2.6 \mathrm{MW}$ among project developers, $825 \mathrm{~kW}$ among farmers and 2 MW among utility-type investors.

\section{Conclusions, implications and suggestions for further research}

\subsection{Conclusions: investor categories and their key differences}

From the empirical data presented in Section 4.2, we can conclude that the share of RESE investments made by emerging investors has increased since the 1990s and that today it is larger than the share of such investments made by utility-type actors in all sources of renewable electricity production in Sweden. The picture given in much of the traditional energy economics literature on the group of RES-E investors is not complete; the group of RES-E investors is not homogenous. On the contrary, there are many different types of investors: utility types (already well-studied in the previous literature), sole traders, publicly-owned non-energy companies and units, associations, farmers, independent power producers (IPPs), project developers and diversified companies.

In line with the suggestions found in the behavioral approach literature (see Section 2.2), these RES-E investor categories differ in a number of ways. First, like financial investors (cf. Wüstenhagen and Menichetti, 2012), they differ in terms of energy market experience. Utility-type investors have a long tradition of producing electricity, whereas many diversified companies, farmers and IPPs are new entrants in this market. However, investors also differ in terms of general business experience, something which has not been discussed much in previous energy literature. Investors such as farmers, diversifying companies and utility-type investors all have previous experience of running a business, whereas others, such as many sole traders and IPPs, do not. Such 
differences are likely to influence how different investor categories make the decision to invest in RES-E and how they go about developing their investment projects. Second, as suggested by, e.g., Dinica (2006), they differ in terms of size and financial strength: utility-type investors and diversifying companies have access to financial resources from their main activities, whereas sole traders or economic associations may have a much more limited starting capital. As discussed in Section 2.2, such differences can influence both the size of investment of different types of RES-E investors and their choice of investment models (cf. Dinica, 2011; Wiser, 1997). Third, investors vary in terms of their internal and external investment contexts. Farmers, for instance, exist in a context where the long-term management of natural resources is in focus and the traditional family values are upheld. In contrast, diversifying companies have to cope with internal competition for resources as well as competition in their main markets. They also have to balance the interest of a much larger set of stakeholders than does the ordinary farmer, sole trader or association. Similarly, IPPs which have renewable electricity production as their main business activity, tend to be more interested in maximizing their profit than do associations, which in the Swedish context, are not allowed to realize any profits. As previously suggested in the literature, this implies that RES-E investorsbackgrounds (Bollinger and Gillingham, 2012; Drury et al., 2012) and motives (Dinica, 2006; Langniss, 1996) may diverge.

Another conclusion from the empirical data is that the constellation of RES-E investors changes from one renewable energy source to the other. For example, IPPs make a majority of the investments in wind power, but are not represented at all among investors in solar PV. Similarly, the types of companies that diversify into RES-E differ from one renewable energy source to another. Companies diversifying into biomassbased power production are primarily from the pulp and paper industry, which is also well represented among companies diversifying into hydro power production. Companies diversifying into solar power include mechanical engineering, construction consultants and real estate companies. Companies diversifying into wind power form a more diverse set, including for example companies involved in agriculture, forestry, property management and construction.

Although further studies are required in order to fully explain these differences, this indicates that RES-E investors' access to specific physical resources, such as input 
materials, wind and water flows or space, play a role in their investment decisions. Pulp and paper companies have good access to biomass in the form of paper fibers and waste for example, and their plants are often located close to streams, since historically they were often ran on hydro power. Real estate companies and manufacturing companies have access to large buildings where they can install roof-top solar PV cells, while farmers, agriculture companies and forestry companies can make use of their own land resources to put up wind turbines. This adds to the existing literature on investment behavior, which, as discussed above, has previously focused primarily on the importance of financial resources.

These results show that RES-E investors are different to each other and that these differences are likely to lead to alternative choices in investment decisions, investment behavior and, thus, policy responsiveness. According to the earlier related studies described in Section 2.2, several factors might be relevant determinants of investment behavior: motives, resources, previous experience and various types of personal characteristics. However, with few exceptions, these have not been studied empirically in the context of RES-E investments, and therefore we do not know which are most important in this context. A micro-level perspective is needed which considers investors' individual differences. We suggest that such a micro-level perspective should be firmly founded in previous research into the relationship between individual characteristics or motives, and investment decisions, i.e. why and how investments take place. Three research fields in particular have conducted comprehensive studies into this issue: the fields of entrepreneurship, innovation adoption and institutional theory. In the next section, we develop a three-dimensional framework which builds on literature from these three fields, as a complement to the standard economic perspective found in much of the energy economics and energy policy literature.

\subsection{A multidimensional framework for analyzing RES-E investors}

We start by introducing the three dimensions and the way in which they can contribute to a better understanding of RES-E investors. We then go on to synthesize these dimensions and identify some topics that should be studied in future research about RES-E investors and the appropriate energy policy choices that will encourage additional RES-E investments. 


\subsubsection{The entrepreneurship dimension}

The entrepreneurship dimension considers the background and motives of investors to facilitate our understanding of how they evaluate and decide to pursue the investments, and how the investment process is developed. In entrepreneurship terminology, this implies that entrepreneurs assess and pursue opportunities through an opportunity exploitation process.

In the entrepreneurship literature, investments occur when an opportunity has been identified and when the value of exploiting that opportunity is high enough for the entrepreneur to take the risk to pursue it (Casson, 1982; Shane and Venkataraman, 2000). As described in Section 4.2, many investors have another main business activity and no background in electricity production. It is therefore legitimate to assume that those investors have been in a situation where they made the decision to grab an opportunity and break with their established investment routines. In that sense, investors can be regarded as entrepreneurs, and investments considered as entrepreneurial actions.

The entrepreneurship dimension focuses on several aspects of the entrepreneurial action. First, entrepreneurs' characteristics are determinant to entrepreneurial action (Kahn, 1996; Kaish and Gilad, 1991; McClelland, 1965; Sarasvathy et al., 1998). One of the goals of the entrepreneurship literature has been to study entrepreneurs' characteristics in order to explain or predict the success of venture creation (Kahn, 1996). According to some authors, the characteristics of the entrepreneur directly affect the perception of the opportunity and whether the opportunity is exploited or not (Keh et al., 2002; Krueger Jr and Brazeal, 1994) . Entrepreneurs are therefore often presented as, optimistic (Cooper et al., 1988), innovative (Schumpeter, 1934) and risk-taking (Mill, 1984).

Second, the nature of the opportunity affects the investment decision (Shane and Venkataraman, 2000). The potential value of an opportunity is the main motive behind the decision to bear the investment cost in terms of risk, time, money or the opportunity cost of not choosing other alternatives (Kirzner, 1973; Schumpeter, 1934; Shane and Venkataraman, 2000). Assessing the value of an opportunity is a cognitive process and individuals may not evaluate an opportunity in the same way. This depends, for instance, on whether they are experienced or not and on their norms and values (Baron, 
2006; Baron and Ensley, 2006; Ucbasaran et al., 2009). Although the value of the opportunity may be decisive, entrepreneurial opportunities are not necessarily profitable (Shane, 2003). Even if the driving-force of the entrepreneurial investment is value-creating, entrepreneurial decisions are not the result of a rational optimization process where mechanical calculations are made based on a defined set of alternatives or criteria (Baumol, 1993).

Once an opportunity has been recognized and the decision to pursue it taken, the final part of the entrepreneurship process is opportunity exploitation. This can be done through the creation of a new organization/firm, by the pursuit of the opportunity within an existing organization, or by selling the opportunity to another existing organization (Shane, 2003). Once the decision to exploit an opportunity has been taken, the main challenge for entrepreneurs is to gather and combine resources such as capital and knowledge (Alvarez and Busenitz, 2001; Brush et al., 2001; Choi et al., 2008; Florida and Kenney, 1988). Such resources can be acquired by creating alliances and partnerships (Hitt et al., 1997; Koza and Lewin, 2000; Koza and Lewin, 1998) or by the creation and development of networks (Birley, 1985; Carsrud et al., 1987). Being able to gather resources implies that entrepreneurs have legitimacy (Aldrich and Fiol, 1994; Deeds et al., 2004; Lounsbury and Glynn, 2001; Santos and Eisenhardt, 2009).

\subsubsection{The innovation adoption dimension}

The innovation-adoption dimension considers differences in an investor's experience or knowledge of the technology, and the characteristics of the technologies available, as well as investors' networks, in order to explain an investor's decision to invest in a new activity. This dimension emphasizes the subjective nature of the evaluation of an investment. In innovation-adoption terminology, this means that innovation-adopters may evolve in different social and technical systems, and that innovations have different personalities. These differences may lead innovation-adopters to adopt the innovation at different stages.

In the innovation adoption literature, investment decisions are neither inevitable nor uniform across a population of potential adopters (cf. MacVaugh and Schiavone, 2010). A number of conditions influence the innovation-decision process, i.e. the process through which an individual or another decision-making unit "passes from first 
knowledge of an innovation, to forming an attitude toward the innovation, to a decision to adopt or reject, to implementation of the new idea, and to confirmation of this decision" (Rogers, 1983, p. 163). First, the characteristics of the potential adopters (e.g. innovativeness, perceived needs/problems and previous experience) influence their awareness of the innovation, theit access to knowledge as to how the innovation works as well as their acquisition of the capabilities needed to use the innovation (MacVaugh and Schiavone, 2010; Rogers, 1983). In particular, it is the innovativeness of different adopter categories that has been the focus of much of the literature (cf. Rogers, 1983): Some people like to take risks and are therefore eager to try out new technologies with low performance; other people are willing to try out relatively crude technologies as long as they see a clear potential benefit; while others want to wait and see in order to learn of earlier adopters or even until a standard has been set and the technology is really proven.

Second, the characteristics of the innovation as perceived by potential adopters influence their attitude towards it. These characteristics include, for example, (i) its perceived relative advantage (Rogers, 1983) in terms of value and profitability (Metcalfe, 1981) or its perceived utility (MacVaugh and Schiavone, 2010), ${ }^{13}$ (ii) its compatibility with existing values and needs (Rogers, 1983) as well as with complementary technologies (MacVaugh and Schiavone, 2010) and (iii) understandability, which is influenced by, for example its degree of complexity and the trialability and visibility of results (cf. Rogers, 1983).

Third, communication patterns and channels influence potential adopters' access to information from those who have adopted the innovation previously and, thus, the evaluation of the innovation. Individuals who are considering adopting an innovation also tend to take into account the attitude which the social community/-ies to which they belong (MacVaugh and Schiavone, 2010) has towards the innovation.

\footnotetext{
${ }^{13}$ When the new technology provides some distinctive functionality or benefit for a particular group of potential adopters, which cannot be adequately provided by the established technologies, this can give rise to a niche market (Levinthal, 1998; Malerba et al., 2007) Niche market customers are willing to pay more or take the risk of adopting a new technology even if it does not perform as well as established technologies with regards to other performance attributes (Adner and Levinthal, 2001), since the advantages of the new technology are valued higher than its disadvantages (e.g. in terms of cost) (Bergek et al., 2008).
} 


\subsubsection{The institutional dimension}

The institutional dimension shows how the different internal and external contexts of investors, e.g. the norms and values shared by investors and their networks, or the effect of regulations and incentives, affect their decisions and investing processes.

The institutional dimension points out that people do not always act rationally, at least not in terms of economic, profit-maximizing criteria (Selznick, 1996). Instead, their behavior and decisions are heavily influenced by their institutional environment in terms of regulatory pressures, norms, values and cognitive rules at individual, organization, industry and society levels (Munir, 2002; Oliver, 1997; Parkhe, 2003; Scott, 1995; Zucker, 1987). ${ }^{14}$

This influence comes in three main forms: (1) Individuals and organizations have to comply with external institutions (e.g. regulations and social norms) to secure the resources needed for survival (Zucker, 1987). (2) Institutions influence what information people select, how they interpret it and what criteria they use to evaluate different action alternatives (Munir, 2002). (3) People use cognitive institutions, such as models and scripts, as tools to deal with uncertainty when making decisions (Zimmerman and Zeitz, 2002).

From an investor point of view, the main implication is that potential investors are not driven only by "efficiency considerations and competitive imperatives" (Munir, 2002, p. 1405), but frequently consider other, more socially oriented criteria when making investment decisions. For example, the legitimacy of a new business opportunity in the eyes of relevant stakeholders can be of more importance than a formal evaluation of its return on investment (Munir, 2002; Zimmerman and Zeitz, 2002; Zucker, 1987); 15 diversifying companies can also use their established evaluation routines in new fields, even if these routines are not appropriate (Oliver, 1997); and investors can use rule of thumb or rely on advice from within their social network instead of making a complete investment analysis. As a consequence, decisions and choices are often inefficient in economic terms (Zucker, 1987).

\footnotetext{
${ }^{14}$ However, this neither implies that actors are passive, nor that institutions cannot be influenced by actors (Zilber (2002); cf. also Dacin et al. (2002)).

15 Indeed, according to an institutional perspective, the traditional ROI calculation is but one of many available institutionalized models to evaluate an investment.
} 


\subsection{Suggestions for further research}

The entrepreneurship, innovation-adoption and institutional dimensions clearly include a large variety of aspects that can contribute to our understanding of emerging RES-E investors and answer questions still unanswered by the standard economic perspective. Among these factors, it is particularly important to consider the following, since they are found in every dimension:

- Motives: What drives investors to invest in RES-E? Is it value creation, as indicated in the entrepreneurship dimension (E)? General benefit, as indicated in the innovation-adoption dimension (IA)? Legitimacy, as indicated in the institutional dimension (I)? The desire to try a new technology (IA)? Or other motives? How do RES-E investors vary in this respect and how do such differences affect their investment decision, e.g. the choice of renewable source?

- Background: What element of their background affects their investment decision? Is it for instance, their previous experience in the area in which they are investing $(E, I A)$, their previous experience in business creation $(E)$, their access to partnerships or alliances $(E)$, their networks $(E, I A)$, their level of education (IA), their norms and values ( $E, I)$ or their legitimacy $(I)$ ? How do RES-E investors vary in this respect and how do such differences affect their investment decision, e.g. the choice of renewable source?

- Resources: Do RES-E investors have capital (E), knowledge ( $E, I A)$, networks (E, $I A, I)$, good reputation (I), information (E)? If not, how to they get access to these resources? Is it by creating partnerships or alliances $(E)$ ? Through their networks (IA, I)? By imitating others (IA, I)? By changing their norms and values (I)? By complying with external institutions (I)? How do RES-E investors vary in this respect and how do such differences affect their investment decision, e.g. the choice of renewable source?

- Personal characteristics: Are there personal characteristics which stand out among RES-E investors? Are they more optimistic (E), risk-taking (E), innovative (IA), interest-driven (IA), adaptable (I), less profit-seeking (E, IA) compared with other investors or with the rest of the population? How do RES-E investors vary 
in this respect and how do such differences affect their investment decision, e.g. the choice of renewable source?

These four factors are clearly related to the influencing factors identified in Section 2.2, but have a much stronger theoretical foundation and also cover a more comprehensive set of motives, resources, background factors and personal characteristics than those discussed there. Studying these aspects will provide with a better understanding of the RES-E investment process from its inception to project implementation, including drivers and blocking mechanisms, project appraisal methods and criteria, and factors that influence investment decisions. Based on such studies, behaviors patterns related to specific types of RES-E investors and/or to specific renewables may be identified. However, such studies have to be made for many countries, to allow a comparison of cases and lead to an understanding if how the national context influences RES-E investment decisions by different types of actors.

An improved understanding of the characteristics and investment processes of different types of RES-E investors will make it possible to study how current energy policy influences investor behavior, what types of investors benefit from the current policy and what type of policy support is needed to stimulate investments by certain types of investors. Applying the multidimensional framework that we propose in this paper can, therefore, provide policy makers with a basis for improving existing policies in the field of renewable electricity.

\section{Acknowledgements}

Financial support from the Swedish Energy Agency is gratefully acknowledged.

\section{References}

Adner, R., Levinthal, D., 2001. Demand Heterogeneity and Technology Evolution: Implications for Product and Process. Management Science 47, 611-628.

Agterbosch, S., Vermeulen, W., Glasbergen, P., 2004. Implementation of wind energy in the Netherlands: the importance of the social-institutional setting. Energy Policy 32, 2049-2066.

Aguilar, F.X., Cai, Z., 2010. Exploratory analysis of prospects for renewable energy private investment in the U.S. Energy Economics 32, 1245-1252.

Aldrich, H.E., Fiol, C.M., 1994. Fools rush in? The institutional context of industry creation. Academy of Management Review 19, 645-670. 
Alvarez, S., A., Busenitz, L., W., 2001. The entrepreneurship of resource-based theory. Journal of Management 27, 755-775.

Awerbuch, S., 2000. Investing in photovoltaics: risk, accounting and the value of new technology. Energy Policy 28, 1023-1035.

Awerbuch, S., 2003. Determining the real cost: why renewable power is more costcompetitive than previously believed. Renewable Energy World 6, 53-61.

Awerbuch, S., 2006. Portfolio-Based Electricity Generation Planning: Policy Implications For Renewables And Energy Security. Mitigation and Adaptation Strategies for Global Change 11, 693-710.

Baron, R.A., 2006. Opportunity Recognition as Pattern Recognition: How Entrepreneurs "Connect the Dots" to Identify New Business Opportunities. The Academy of Management Journal 20, 104-119.

Baron, R.A., Ensley, M., D., 2006. Opportunity Recognition as the Detection of Meaningful Patterns: Evidence from Comparisons of Novice and Experienced Entrepreneurs Management Science 52, 1331-1344.

Barradale, M.J., 2010. Impact of public policy uncertainty on renewable energy investment: Wind power and the production tax credit. Energy Policy 38, 7698-7709. Baumol, W.J., 1993. Formal entrepreneurship theory in economics: Existence and bounds. Journal of Business Venturing 8, 197-210.

Bemis, G.R., DoAngelis, M., 1990. Levelized cost of electricity generation technologies. Contemporary Economic Policy 8, 200-214.

Bergek, A., Hekkert, M., Jacobsson, S., 2008. Functions in innovation systems: A framework for analysing energy system dynamics and identifying goals for systembuilding activities by entrepreneurs and policy makers, in: Foxon, T., Köhler, J., Oughton, C. (Eds.), Innovation for a Low Carbon Economy: Economic, Institutional and Management Approaches. Edward Elgar, Cheltenham.

Bhattacharya, A., Kojima, S., 2012. Power sector investment risk and renewable energy: A Japanese case study using portfolio risk optimization method. Energy Policy 40, 69-80. Bird, L., Bolinger, M., Gagliano, T., Wiser, R., Brown, M., Parsons, B., 2005. Policies and market factors driving wind power development in the United States. Energy Policy 33, 1397-1407.

Birley, S., 1985. The role of networks in the entrepreneurial process. Journal of Business Venturing 1, 107-117.

Bloomberg New Energy Finance, 2010. Global Trends in Sustainable Energy Investments 2010, Paris.

Bode, S., Michaelowa, A., 2003. Avoiding perverse effects of baseline and investment additionality determination in the case of renewable energy projects. Energy Policy 31, 505-517.

Bolinger, M., Harper, J., Karcher, M., 2009. A review of wind project financing structures in the USA. Wind Energy 12, 295-309.

Bolinger, M., Wiser, R., 2006. A comparative analysis of business structures suitable for farmer-owned wind power projects in the United States. Energy Policy 34, 1750-1761. Bollinger, B., Gillingham, K., 2012. Peer Effects in the Diffusion of Solar Photovoltaic Panels. Marketing Science.

Brush, C.G., Greene, P.G., Hart, M.M., 2001. From initial idea to unique advantage: The entrepreneurial challenge of constructing a resource base. Academy of Management Executive 15, 64-78.

Carlson, A., 2002. On cost-effective technical measures to avoid environmental damages of regional energy systems. International Journal of Energy Research 26, 1103-1115. 
Carsrud, A.L., Gaglio, C.M., Olm, K.W., Churchill, N.C., 1987. Entrepreneurs--Mentors, Networks, and Successful New Venture Development: An Exploratory Study. American Journal of Small Business 12, 13-18.

Casson, M.C., 1982. The Entrepreneur: An Economic Theory. Martin Robertson, Oxford. Choi, Y.R., Lévesque, M., Shepherd, D.A., 2008. When should entrepreneurs expedite or delay opportunity exploitation? Journal of Business Venturing 23, 333-355.

Cooper, A.C., Woo, C.Y., Dunkelberg, W.C., 1988. Entrepreneurs' perceived chances for success. Journal of Business Venturing 3, 97-108.

Couture, T., Gagnon, Y., 2010. An analysis of feed-in tariff remuneration models: Implications for renewable energy investment. Energy Policy 38, 955-965.

Dacin, M.T., Goodstein, J., Scott, W.R., 2002. Institutional theory and institutional change: Introduction to the special research forum. Academy of Management Journal 45, 45-57. Deeds, D.L., Mang, P.Y., Frandsen, M.L., 2004. The Influence of Firms' and Industries' Legitimacy on the Flow of Capital into High-Technology Ventures. Strategic Organization 2, 9-34.

Delmas, M.A., Montes-Sancho, M.J., 2011. U.S. state policies for renewable energy: Context and effectiveness. Energy Policy 39, 2273-2288.

Dinica, V., 2006. Support systems for the diffusion of renewable energy technologiesan investor perspective. Energy Policy 34, 461-480.

Dinica, V., 2011. Renewable electricity production costs-A framework to assist policymakers' decisions on price support. Energy Policy 39, 4153-4167.

Donovan, C., Nuñez, L., 2012. Figuring what's fair: The cost of equity capital for renewable energy in emerging markets. Energy Policy 40, 49-58.

Drury, E., Miller, M., Macal, C.M., Graziano, D.J., Heimiller, D., Ozik, J., Perry Iv, T.D., 2012. The transformation of southern California's residential photovoltaics market through third-party ownership. Energy Policy 42, 681-690.

Enzensberger, N., Wietschel, M., Rentz, 0., 2002. Policy instruments fostering wind energy projects-a multi-perspective evaluation approach. Energy Policy 30, 793-801. Faúndez, P., 2008. Renewable energy in a market-based economy: How to estimate its potential and choose the right incentives. Renewable Energy 33, 1768-1774.

Finon, D., Perez, Y., 2007. The social efficiency of instruments of promotion of renewable energies: A transaction-cost perspective. Ecological Economics 62, 77-92.

Fleten, S.E., Maribu, K.M., Wangensteen, I., 2007. Optimal investment strategies in decentralized renewable power generation under uncertainty. Energy 32, 803-815.

Florida, R., Kenney, M., 1988. Venture capital and high technology entrepreneurship. Journal of Business Venturing 3, 301-319.

Gross, R., Blyth, W., Heptonstall, P., 2010. Risks, revenues and investment in electricity generation: Why policy needs to look beyond costs. Energy Economics 32, 796-804.

Hitt, M.A., Ireland, R.D., Hoskisson, R.E., 1997. Strategic Management: Competitiveness \& Globalization, Concepts, 9 ed. West Publishing Co., St Paul, MN.

Huang, Y.-H., Wu, J.-H., 2008. A portfolio risk analysis on electricity supply planning. Energy Policy 36, 627-641.

IPCC, 2011. Special Report on Renewable Energy Sources and Climate Change Mitigation (SRREN), in: Edenhofer, O., Pichs-Madruga, R., Sokona, Y., Seyboth, K., Matschoss, P., Kadner, S., Zwickel, T., Eickemeier, P., Hansen, G., Schlömer, S., von Stechow, C. (Eds.), Cambridge.

Jacobsson, S., Bergek, A., 2011. Innovation system analyses and sustainability transitions: Contributions and suggestions for research. Environmental Innovation and Societal Transitions 1, 41-57. 
Johnson, A., Jacobsson, S., 2001. Inducement and Blocking Mechanisms in the Development of a New Industry: The Case of Renewable Energy Technology in Sweden, in: Coombs, R., Green, K., Walsh, V., Richards, A. (Eds.), Technology and the Market: Demand, Users and Innovation. Edward Elgar, Cheltenham/Northhampton.

Kahn, E., 1996. The production tax credit for wind turbine powerplants is an ineffective incentive. Energy Policy 24, 427-435.

Kaish, S., Gilad, B., 1991. Characteristics of opportunities search of entrepreneurs versus executives: Sources, interests, general alertness. Journal of Business Venturing 6, 45-61. Kangas, H.-L., Lintunen, J., Pohjola, J., Hetemäki, L., Uusivuori, J., 2011. Investments into forest biorefineries under different price and policy structures. Energy Economics 33, 1165-1176.

Keh, H.T., Foo, M.D., Lim, B.C., 2002. Opportunity Evaluation under Risky Conditions: The Cognitive Processes of Entrepreneurs. Entrepreneurship Theory and Practice 27, 125148.

Kirzner, I., 1973. Competition and Entrepreneurship. University of Chicago Press, Chicago.

Koo, J., Park, K., Shin, D., Yoon, E.S., 2011. Economic evaluation of renewable energy systems under varying scenarios and its implications to Korea's renewable energy plan. Applied Energy 88, 2254-2260.

Koza, M., Lewin, A., 2000. Managing partnerships and strategic alliances: raising the odds of success. European Management Journal 18, 146-151.

Koza, M.P., Lewin, A.Y., 1998. The Co-Evolution of Strategic Alliances. Organization Science 9, 255-264.

Krueger Jr, N.F., Brazeal, D.V., 1994. Entrepreneurial Potential and Potential Entrepreneurs. Entrepreneurship: Theory \& Practice 18, 91-104.

Langniss, 0., 1996. Instruments to foster renewable energy investments in Europe a survey under the financial point of view. Renewable Energy 9, 1112-1115.

Levinthal, D.A., 1998. The Slow Pace of Rapid Technological Change: Gradualism and Punctuation in Technological Change. Industrial and Corporate Change 7, 217-247. Loock, M., 2012. Going beyond best technology and lowest price: on renewable energy investors' preference for service-driven business models. Energy Policy 40, 21-27. Lounsbury, M., Glynn, M.A., 2001. Cultural entrepreneurship: stories, legitimacy, and the acquisition of resources. Strategic Management Journal 22, 545-564.

MacVaugh, J., Schiavone, F., 2010. Limits to the diffusion of innovation: A literature review and integrative model. European Journal of Innovation Management 13, 197221.

Madlener, R., Kumbaroğlu, G., Ediger, V.Ş., 2005. Modeling technology adoption as an irreversible investment under uncertainty: the case of the Turkish electricity supply industry. Energy Economics 27, 139-163.

Malerba, F., Nelson, R.R., Orsenigo, L., Winter, S., 2007. Demand, innovation, and the dynamics of market structure: The role of experimental users and diverse preferences. Journal of Evolutionary Economics 17, 371-399.

Masini, A., Menichetti, E., 2012. The impact of behavioural factors in the renewable energy investment decision making process: Conceptual framework and empirical findings. Energy Policy 40, 28-38.

McClelland, D.C., 1965. Achievement and entrepreneurship. Journal of Personality and Social Psychology Vol 1, 389-392.

McVeigh, J., Burtraw, D., Darmstadter, J., Palmer, K., 2000. Winner, loser, or innocent victim? Has renewable energy performed as expected? Solar Energy 68, 237-255. 
Metcalfe, J.S., 1981. Impulse and diffusion in the study of technical change. Futures 13, 347-359.

Mill, J.S. (Ed.), 1984. Principles of Political Economy with Some Applications to Social Philosophy. John W. Parker, London.

Munir, K.A., 2002. Being different: How normative and cognitive aspects of institutional environments influence technology. Human Relations 55, 1403-1428.

Muñoz, J.I., Sánchez de la Nieta, A.A., Contreras, J., Bernal-Agustín, J.L., 2009. Optimal investment portfolio in renewable energy: The Spanish case. Energy Policy 37, 52735284.

Neuhoff, K., Ehrenmann, A., Butler, L., Cust, J., Hoexter, H., Keats, K., Kreczko, A., Sinden, G., 2008. Space and time: Wind in an investment planning model. Energy Economics 30, 1990-2008.

Nordic competition authorities, 2003. A Powerful Competition Policy: Towards a more coherent competition policy in the Nordic market for electric power. The Nordic competition authorities, Copenhagen, Oslo and Stockholm.

Oliver, C., 1997. Sustainable Competitive Advantage: Combining Institutional and Resource-Based Views. Strategic Management Journal 18, 697-713.

Parkhe, A., 2003. Institutional environments, institutional change and international alliances. Journal of International Management 9, 305-316.

Pettersson, F., Söderholm, P., 2009. The diffusion of renewable electricity in the presence of climate policy and technology learning: The case of Sweden. Renewable and Sustainable Energy Reviews 13, 2031-2040.

Rogers, E.M., 1983. Diffusion of Innovations, 3rd ed. The Free Press, New York. Santos, F., Eisenhardt, K., 2009. Constructing Markets and Shaping Boundaries: Entrepreneurial Power in Nascent Fields. The Academy of Management Journal ARCHIVE 52, 643-671.

Sarasvathy, D.K., Simon, H.A., Lave, L., 1998. Perceiving and managing business risks: differences between entrepreneurs and bankers. Journal of Economic Behavior \&amp; Organization 33, 207-225.

Schumpeter, J. (Ed.), 1934. The Theory of Economic Development. Harvard University Press, Cambridge, Mass.

Scott, W.R., 1995. Institutions and Organizations. Sage Publications, Thousand Oaks. Selznick, P., 1996. Institutionalism "Old" and "New". Administrative Science Quarterly 41, 270-277.

Shane, S., 2003. A General Theory of Entrepreneurship. The Individual-Opportunity Nexus, 2003 ed. Edward Elgar, Cheltenham.

Shane, S., Venkataraman, S., 2000. The Promise of Entrepreneurship as a Field of Research. The Academy of Management Review 25, 217-226.

Swedish Energy Agency, 2011a. Elcertifikatsystemet 2011, Eskilstuna.

Swedish Energy Agency, 2011b. Energy in Sweden 2011 Facts and Figures., Eskilstuna. Söderholm, P., Ek, K., Pettersson, M., 2007. Wind power development in Sweden: Global policies and local obstacles. Renewable and Sustainable Energy Reviews 11, 365-400. Söderholm, P., Klaassen, G., 2007. Wind Power in Europe: A Simultaneous InnovationDiffusion Model. Environmental and Resource Economics 36, 163-190.

Söderholm, P., Pettersson, M., 2011. Offshore wind power policy and planning in Sweden. Energy Policy 39, 518-525.

Tsoutsos, T., Drandaki, M., Frantzeskaki, N., Iosifidis, E., Kiosses, I., 2009. Sustainable energy planning by using multi-criteria analysis application in the island of Crete.

Energy Policy 37, 1587-1600. 
Ucbasaran, D., Westhead, P., Wright, M., 2009. The extent and nature of opportunity identification by experienced entrepreneurs. Journal of Business Venturing 24, 99-115. Wiser, R.H., 1997. Renewable energy finance and project ownership: The impact of alternative development structures on the cost of wind power. Energy Policy 25, 15-27. Wüstenhagen, R., Menichetti, E., 2012. Strategic choices for renewable energy investment: Conceptual framework and opportunities for further research. Energy Policy 40, 1-10.

Zilber, T.B., 2002. Institutionalization as an Interplay between Actions, Meanings, and Actors: The Case of a Rape Crisis Center in Israel. The Academy of Management Journal 45, 234-254.

Zimmerman, M.A., Zeitz, G.J.f., 2002. Beyound survival: Achieving new venture growth by building legitimacy. Academy of Management Review 27, 414-431.

Zucker, L.G., 1987. Institutional Theories of Organization. Annual Review of Sociology $13,443-464$. 
TABLE 1: ASSUMPTIONS ABOUT INVESTORS IN RENEWABLE ELECTRICITY PRODUCTION IN PREVIOUS LITERATURE (ECONOMIC-RATIONAL APPROACH)

\begin{tabular}{|c|c|c|c|c|}
\hline & $\begin{array}{c}\text { (A) } \\
\text { Investments been compared }\end{array}$ & $\begin{array}{c}\text { (B) } \\
\text { Main evaluation criteria }\end{array}$ & $\begin{array}{c}\text { (C) } \\
\text { Additional cost or revenue } \\
\text { factors considered (other } \\
\text { than engineering costs) } \\
\end{array}$ & $\begin{array}{l}\text { (D) } \\
\text { Who is the investor and what is the scale and character of } \\
\text { investments? }\end{array}$ \\
\hline $\begin{array}{l}\text { Awerbuch } \\
(2003)\end{array}$ & $\begin{array}{l}\text { Fossil vs. renewable } \\
\text { (conventional fossil-fired technologies vs. } \\
\text { renewable alternatives) }\end{array}$ & Risk-adjusted costs & $\begin{array}{l}\text { Market risk (e.g. fossil price } \\
\text { volatility) }\end{array}$ & $\begin{array}{l}\text { Energy planner } \\
\text { Investment scale: not specified }\end{array}$ \\
\hline $\begin{array}{l}\text { Awerbuch } \\
(2006)\end{array}$ & $\begin{array}{l}\text { Fossil vs. renewable } \\
\text { (fossil-dominated energy investments vs. } \\
\text { portfolio investments including a share of } \\
\text { renewable energy investments) }\end{array}$ & Portfolio generating cost & $\begin{array}{l}\text { Market risk (e.g. fossil price } \\
\text { volatility) }\end{array}$ & $\begin{array}{l}\text { Electricity planner } \\
\text { Investment scale: not specified (portfolio of generation) }\end{array}$ \\
\hline $\begin{array}{l}\text { Bhattacharya } \\
\text { \& Kojima } \\
\text { (2012) }\end{array}$ & $\begin{array}{l}\text { Fossil vs. fossil + renewable } \\
\text { (fossil-dominated energy investments vs. } \\
\text { portfolio investments including a share of } \\
\text { renewable energy investments) }\end{array}$ & Portfolio generating costs & Portfolio risk & $\begin{array}{l}\text { Energy planner } \\
\text { Investment scale: not specified (portfolio of generation) }\end{array}$ \\
\hline $\begin{array}{l}\text { Bode \& } \\
\text { Michaelowa } \\
(2003)\end{array}$ & $\begin{array}{l}\text { Fossil vs. renewable } \\
\text { (conventional vs. renewable energy } \\
\text { projects) }\end{array}$ & Internal rate of return & $\begin{array}{l}\text { Revenues: price of electricity } \\
\text { and price of emission } \\
\text { reduction shares }\end{array}$ & $\begin{array}{l}\text { Individual investor trying to maximize profits. } \\
\text { Chooses the site with the maximum expected yield of energy. } \\
\text { Investment scale: } 750 \mathrm{~kW} \text { (wind) and } 130 \mathrm{~kW}_{\mathrm{p}} \text { (solar PV). }\end{array}$ \\
\hline $\begin{array}{l}\text { Carlson } \\
(2002)\end{array}$ & $\begin{array}{l}\text { Fossil vs. renewable }+ \text { fossil } \\
\text { (fossil-fuels vs. mix of woody biomass and } \\
\text { fossil-fuels) }\end{array}$ & Overall energy system cost & $\begin{array}{l}\text { External costs (societal costs } \\
\text { and environmental costs) }\end{array}$ & $\begin{array}{l}\text { Energy planner aiming at finding the optimal mix of energy } \\
\text { carriers in a regional energy system } \\
\text { Investment scale: } 2.5-28.2 \mathrm{MW} \text { (biomass) (entire regional energy } \\
\text { system modeled) }\end{array}$ \\
\hline Dinica (2011) & $\begin{array}{l}\text { Renewable vs. renewable } \\
\text { (investment in renewables at different } \\
\text { locations (policy perspective)) }\end{array}$ & Overall production cost & $\begin{array}{l}\text { A variety of costs, e.g. } \\
\text { financing costs, insurance } \\
\text { cost and costs for trade } \\
\text { arrangements; } \\
\text { decommissioning costs; } \\
\text { project permitting costs }\end{array}$ & $\begin{array}{l}\text { Developer trying to minimize production costs } \\
\text { Pursues the locations with best resources first (i.e. can choose } \\
\text { between different locations). } \\
\text { Investment scale: } 20-35 \mathrm{MW} \text { (wind) }\end{array}$ \\
\hline $\begin{array}{l}\text { Donovan \& } \\
\text { Nuñez }(2012)\end{array}$ & $\begin{array}{l}\text { Renewable vs. renewable } \\
\text { (investment in renewable energy made by } \\
\text { domestic firms vs. investment in } \\
\text { renewable energy made by foreign firms } \\
\text { in China, India and Brazil) }\end{array}$ & $\begin{array}{l}\text { Return on investment (net } \\
\text { present value) }\end{array}$ & Market risk & $\begin{array}{l}\text { Renewable energy firm } \\
\text { Investment scale: not specified }\end{array}$ \\
\hline $\begin{array}{l}\text { Faúndez } \\
\text { (2008) }\end{array}$ & $\begin{array}{l}\text { Renewable vs. renewable } \\
\text { (investments in wind power in different } \\
\text { sites) }\end{array}$ & $\begin{array}{l}\text { Marginal efficiency of capital } \\
\text { considering energy transport } \\
\text { distance and productivity of } \\
\text { site) }\end{array}$ & $\begin{array}{l}\text { Costs related to the project } \\
\text { site (e.g. energy transport } \\
\text { distance) } \\
\text { Revenues: productivity of }\end{array}$ & $\begin{array}{l}\text { Profit maximizing investor } \\
\text { Sites are chosen based on productivity. } \\
\text { Investment scale: } 38-62 \mathrm{MW} \text { (wind power) }\end{array}$ \\
\hline
\end{tabular}




\begin{tabular}{|c|c|c|c|c|}
\hline & & & $\begin{array}{l}\text { site, emissions reduction } \\
\text { certificates sales }\end{array}$ & \\
\hline $\begin{array}{l}\text { Finon \& Perez } \\
(2007)\end{array}$ & $\begin{array}{l}\text { Renewable vs. renewable } \\
\text { (investments in renewable energy under } \\
\text { feed-in tariffs vs. investments in } \\
\text { renewable energy under RES-E quota) }\end{array}$ & $\begin{array}{l}\text { Investment costs } \\
\text { - Operational performances of } \\
\text { the plants }\end{array}$ & $\begin{array}{l}\text { Political risk/uncertainty } \\
\text { related to the long-term } \\
\text { unpredictability of support } \\
\text { systems }\end{array}$ & $\begin{array}{l}\text { Investor-producers (the range of investor-producers includes } \\
\text { low-sized suppliers and public utility industries) } \\
\text { Investment scale: not specified }\end{array}$ \\
\hline $\begin{array}{l}\text { Fleten et al. } \\
(2007)\end{array}$ & $\begin{array}{l}\text { Renewable vs. renewable and renewable } \\
\text { vs. postponing } \\
\text { (investment in projects of different sizes } \\
\text { within the same type of electricity } \\
\text { generation technology, with the option to } \\
\text { postpone the investment) }\end{array}$ & Net present value & $\begin{array}{l}\text { Revenues: value of displaced } \\
\text { electricity and exported } \\
\text { electricity; price uncertainty }\end{array}$ & $\begin{array}{l}\text { Building owner who wants to maximize private profits, with a } \\
\text { building that consumes electricity and has a renewable resource } \\
\text { available. } \\
\text { Maximum capacity, constrained by resource availability or } \\
\text { regulation: } 250 \mathrm{~kW} \text { (wind) }\end{array}$ \\
\hline $\begin{array}{l}\text { Huang \& Wu } \\
(2008)\end{array}$ & $\begin{array}{l}\text { Fossil vs. renewable and renewable vs. } \\
\text { renewable } \\
\text { (investments in coal, oil and gas thermal } \\
\text { power vs. investments in hydro, wind, } \\
\text { solar PV, waste, biomass, and geothermal) }\end{array}$ & $\begin{array}{l}\text { Risk-weighted present value of } \\
\text { total generation cost (under } \\
\text { some energy planning } \\
\text { constraints, e.g. load duration,) }\end{array}$ & $\begin{array}{l}\text { Cost-related risks (fluctuation } \\
\text { in fuel price, technological } \\
\text { progress and capital cost } \\
\text { reduction) }\end{array}$ & $\begin{array}{l}\text { Energy planner } \\
\text { Investment scale: unclear (but max } 500 \mathrm{MW} \text { wind power per } \\
\text { year) }\end{array}$ \\
\hline Kahn (1996) & $\begin{array}{l}\text { Fossil vs. renewable } \\
\text { (investment in conventional power } \\
\text { technology vs. investments in wind } \\
\text { turbine power plants) }\end{array}$ & $\begin{array}{l}\text { Expected rate of return (capital } \\
\text { asset pricing model) }\end{array}$ & $\begin{array}{l}\text { Cost of risk } \\
\text { Financing cost (interest rate, } \\
\text { debt maturity, capital } \\
\text { structure and cost of equity) } \\
\text { Production tax credit (cost } \\
\text { reduction) }\end{array}$ & $\begin{array}{l}\text { Private power producer } \\
\text { Finances projects on a stand-alone basis and, therefore, relies } \\
\text { more on bank loans and other forms of private borrowing. } \\
\text { Investment scale: } 14.5 \mathrm{MW}-67 \mathrm{MW} \text { (wind) and } 99 \mathrm{MW}-1000 \mathrm{MW} \\
\text { (conventional) }\end{array}$ \\
\hline $\begin{array}{l}\text { Madlener et } \\
\text { al. (2005) }\end{array}$ & $\begin{array}{l}\text { Fossil vs. fossil and renewable } \\
\text { (investments in different types of fossil, } \\
\text { thermal power, hydro power and } \\
\text { geothermal power plants) }\end{array}$ & $\begin{array}{l}\text { Net present value of electricity } \\
\text { production }\end{array}$ & $\begin{array}{l}\text { Demand uncertainty and } \\
\text { timing of investment decision } \\
\text { (real options approach) }\end{array}$ & $\begin{array}{l}\text { Value maximizing investor in competitive market } \\
\text { Investment scale: not specified (national energy system) }\end{array}$ \\
\hline $\begin{array}{l}\text { Muñoz et al. } \\
(2009)\end{array}$ & $\begin{array}{l}\text { Renewable vs. renewable } \\
\text { (investments in wind power vs. } \\
\text { photovoltaic vs. mini hydro vs. thermo } \\
\text { electrical) }\end{array}$ & Internal rate of return & $\begin{array}{l}\text { Risks } \\
\text { Revenues: electricity sales }+ \\
\text { bonus (determined by policy) }\end{array}$ & $\begin{array}{l}\text { Private investor who wants to maximize profits and minimize } \\
\text { risks. } \\
\text { Investment scale: } 10 \mathrm{MW} \text { (wind), } 700 \mathrm{~kW}_{\mathrm{p}} \text { (solar PV), } 5 \mathrm{MW} \\
\text { (mini hydro) and } 50 \mathrm{MW} \text { (thermo electrical). }\end{array}$ \\
\hline $\begin{array}{l}\text { Neuhoff et al. } \\
(2008)\end{array}$ & $\begin{array}{l}\text { Renewable vs. renewable + renewable vs. } \\
\text { fossil } \\
\text { (investment in wind power in different } \\
\text { regions; other options: CCGT and open } \\
\text { cycle gas turbines) }\end{array}$ & $\begin{array}{l}\text { Present value of production and } \\
\text { investment costs }\end{array}$ & $\begin{array}{l}\text { Site-specific wind output } \\
\text { conditions } \\
\mathrm{CO}_{2} \text { allowance costs }\end{array}$ & $\begin{array}{l}\text { Energy planner } \\
\text { Investment scale: } 0.5 \mathrm{GW} \text { (wind) per region and year }\end{array}$ \\
\hline
\end{tabular}




\begin{tabular}{|c|c|c|c|c|}
\hline $\begin{array}{l}\text { Pettersson \& } \\
\text { Söderholm } \\
\text { (2009) }\end{array}$ & $\begin{array}{l}\text { Fossil vs. renewable, renewable vs. } \\
\text { renewable and fossil vs. fossil } \\
\text { (comparison between combined cycle gas } \\
\text { turbine, biomass CHP, coal steam cycle, } \\
\text { coal CCS, waste CHP, wind onshore, wind } \\
\text { offshore and nuclear) }\end{array}$ & $\begin{array}{l}\text { Lifetime engineering costs } \\
\text { (investment, operation \& } \\
\text { maintenance and fuel costs) } \\
\text { under different rates-of-return }\end{array}$ & $\begin{array}{l}\text { Cost of } \mathrm{CO}_{2} \text { emission } \\
\text { allowances } \\
\text { Impact of tradable green } \\
\text { certificates as well as } \\
\text { environmental fees, taxes and } \\
\text { bonuses (in terms of cost } \\
\text { reduction) } \\
\text { Carbon pricing }\end{array}$ & $\begin{array}{l}\text { Power generator who considers investing in new generation } \\
\text { capacity } \\
\text { Investment scale: } 4.25 / 40 \mathrm{MW} \text { (onshore wind), } 150 / 750 \mathrm{MW} \\
\text { (offshore wind) and } 80 \mathrm{MW} \text { (biomass CHP). }\end{array}$ \\
\hline $\begin{array}{l}\text { Söderholm \& } \\
\text { Klaassen } \\
(2007)\end{array}$ & $\begin{array}{l}\text { Fossil vs. renewable } \\
\text { (price paid for coal in the electricity } \\
\text { market taken into account when deciding } \\
\text { whether to invest in a wind turbine)) }\end{array}$ & $\begin{array}{l}\text { Profits (investment costs, } \\
\text { including wind turbine, grid } \\
\text { connection, foundations and } \\
\text { electrical connections) }\end{array}$ & $\begin{array}{l}\text { Costs for environmental } \\
\text { assessment and territorial } \\
\text { planning (indirect) } \\
\text { Revenues: electricity feed-in } \\
\text { prices }\end{array}$ & $\begin{array}{l}\text { Profit-maximizing power generator who can choose an optimal } \\
\text { level of wind power capacity to invest in } \\
\text { Investment scale: not specified }\end{array}$ \\
\hline $\begin{array}{l}\text { Söderholm et } \\
\text { al. (2007) }\end{array}$ & $\begin{array}{l}\text { Fossil vs. renewable and renewable vs. } \\
\text { renewable } \\
\text { (onshore wind power vs. offshore wind } \\
\text { power vs. coal power plant, coal CHP, gas } \\
\text { power plant, gas CHP, biofuel CHP and } \\
\text { hydropower) }\end{array}$ & $\begin{array}{l}\text { Levelized (lifetime) costs, } \\
\text { including investment costs and } \\
\text { generation costs }\end{array}$ & $\begin{array}{l}\text { Uncertainties and risks } \\
\text { (different discount rates) } \\
\text { Costs (for fossil fuels): } \\
\text { emission taxes and carbon } \\
\text { pricing } \\
\text { Revenues (for renewables): } \\
\text { certificate prices (treated as } \\
\text { cost reductions), }\end{array}$ & $\begin{array}{l}\text { Power generator who considers investing in new wind mills. } \\
\text { Investment scale: } 20 \mathrm{MW} \text { (onshore wind), } 90 \mathrm{MW} \text { (offshore } \\
\text { wind), and } 80 \mathrm{MW} \text { (biomass CHP). }\end{array}$ \\
\hline $\begin{array}{l}\text { Tsoutsos et al. } \\
(2009)\end{array}$ & $\begin{array}{l}\text { Renewable vs. renewable } \\
\text { (different mixes of renewables in a } \\
\text { portfolio) }\end{array}$ & $\begin{array}{l}\text { Multi-criteria analysis; analysis } \\
\text { of potential investors focuses } \\
\text { on investment cost }\end{array}$ & $\begin{array}{l}\text { Revenues: safety of supply } \\
\text { (reliability) } \\
\text { Other criteria: maturity of } \\
\text { technology }\end{array}$ & $\begin{array}{l}\text { Energy planners (multiple actors involved; here only focus on } \\
\text { potential investors) } \\
\text { Investment scale: } 88-253 \text { million Euro (shared by a non-specified } \\
\text { number of investors), e.g. } 632 \mathrm{MW} \text { wind turbines, distributed } \\
\text { over several regions. }\end{array}$ \\
\hline
\end{tabular}

